VS Publications

Alford Council of International English \& Literature Journal(ACIELJ)

Impact Factor:4.401(SJIF)An International Peer-Reviewed English Journal

www.acielj.com

Vol-3,Issue-2,2020

ISSN:2581-6500

\title{
TITLE:RURALITY/URBANITY IN THE NINETEENTH CENTURY: WUTHERING HEIGHTS AS A CASE STUDY
}

\author{
Alaa L. Alnajm \\ University of Kufa ,Iraq \\ Email: alaal.alnajm@uokufa.edu.iq
}

\section{Abstract}

This paper investigates the rural/urban oppositions in the nineteenth century. It studies Emily Bronte's Wuthering Heights as a case study to show how these two oppositional issues set the structure of the novel. The study also gives an account about the nature of rural/urban contractions in the European society of 19th century particularly England. The urban and the rural comprise a well-known duality. They assume a job in shaping personality, in setting up land classifications, and in making social contrast. This postulation adopts a basic strategy to comprehension the urban and rural, which involves investigating them as socially built substances. However; since the significance of rurality is inseparably bound up with that of urbanity, it is difficult to isolate them totally.

The construction of rural is drawn closer through an investigation of the complexities of its importance inside different types of talk. Furthermore; the paper takes the counter essentialist position that rurality is a fanciful area emerging from specific social, historical and cultural circumstances. The importance of rurality is temperamental, self-assertive and subject to potential change. It is pervaded with values, which position it progressively comparable to the urban. The paper expands on the assessment of rurality as an ideologically pervaded development, by investigating the conditions of its creation. The methodology utilized isn't just to search for material conditions to frame central causal clarifications for the production of a urban/provincial twofold, since these causes are themselves digressive developments. Rather, material social and social talks are watched, which meet up to frame rural centrality. The concept of nature is drawn nearer comparable to its developed inverse: the civilized. The civilisation/nature twofold is adjusted by relationship with that of the urban/rural. Furthermore, thought is given to the association among this and frontier thoughts of the domination of Western civilisation over the savage other. Translations are made concerning Western belief systems of control through the utilization of Bakhtinian thoughts of the bizarre so as to give another viewpoint on the ideal and hostile to ideal highlights of the rural which rise up out of Wuthering Heights.

Keywords: Urbanity, Rurality, Wuthering Heights, nature, and history.

\section{Introduction}

The main aspect of everyday experience is opposition. The presence of oppositional ideas, for example, 'love and 
VS Publications

Alford Council of International English \& Literature Journal(ACIELJ)

Impact Factor:4.401(SJIF)An International Peer-Reviewed English Journal

www.acielj.com

Vol-3,Issue-2,2020

ISSN:2581-6500

hatred, 'sweet and bitter', 'hot and cold' gives off an impression of being a goal reality, an overseeing rule of the universe. However, people in their experiences understand and see opposition as it is reflected-on or lived. One of the basic features of semiotic and critical analysis is the binary or the opposite; moreover it is perceived as 'one of the most significant standards overseeing the structure of languages. (Lyons, 1977, p.271) and 'a key and fundamental activity of the human thinking (Hawkes, 2003, p.13). The idea is recognizable in the investigation of different social constructs, and has known cultural groups from very old times.

Definitely the system of binary pairs is explored by Aristotle: the four paired elements of earth/air and fire/water. Additionally form/matter, natural/unnatural, active/passive, whole/part, unity/variety, before/after, being/not-being are identified by him; in a very deep sense, Aristotle studies this throughout Book 10 (Iota) of Metaphysics. Therefore, oppositional concepts are fundamentally unrelated. For instance, the temperature of water can be shown on a size of hot, or cold. It tends to be named 'hot' or 'cold', or something in the middle of - 'lukewarm' maybe. In any case, it is beyond the realm of imagination to expect to make the water both more hotter and colder simultaneously. This idea is verifiable in Aristotle's attestation of the law of logical inconsistency: "it is impossible for anything at the same time to be and not to be"(McKeon, 1941, p.737). Paul de Man depicts this idea as 'the most certain of all principles'(de Man, 1979, p. 120).
This paper approaches binary as social constructs, whose presence is literary and conceptual, instead of subjective or material. The examination of oppositions, and of the urban/rural specifically, is hence worried about implication inside the text. Binaries are exclusive ; in that capacity, they are built through the procedure of meaning. Accordingly, the cultural and historical of some changes in values and concepts would be affect them.

Urban/rural difference in reading literature texts is maybe a simple question of realizing the realm of this hierarchy. However; a particularly text shown to be assumed and expressed the systematic order is not merely the representation of literature of urbanity/rurality. It is highly important to understand and study the oppositional characteristic features in Wuthering Heights; furthermore,they will provide very useful perspectives in this story when the application of urban/rural polarities are exposed. Frith adds: "Critics have long seen Wuthering Heights in terms of conflicting polarities: hell/heaven, calm/storm, fair/dark, Heights/Grange... [it is the] instability of the text's apparent polarizations that now attracts most interest"(Frith, 1997, p.243).

The urban and the rural form a recognizable duality. However; they have a very significant role in shaping identity , in setting up land classifications, and in making social and cultural diversity. This paper adopts a basic strategy to comprehension the urban and rural, which involves investigating them as socially developed substances.

An obvious picture about the meaning of rurality is given by Raymond Williams(1973). However; he thinks that 
VS Publications

Alford Council of International English \& Literature Journal(ACIELJ)

Impact Factor:4.401(SJIF)An International Peer-Reviewed English Journal

www.acielj.com

Vol-3,Issue-2,2020

ISSN:2581-6500

country provides growth to a mix of positive connections which mirror 'a characteristic lifestyle: harmony, blamelessness and basic prudence' (p.1). All the while, there are negative undertones: 'backwardness, obliviousness and constraint'. The city, is comparably implanted with a blend of positive and negative meanings: from one perspective with accomplishment, 'learning, correspondence and light', however on the other, with 'commotion, experience and aspiration', but on the other, with hope, ambition and noise. Therefore, through human endeavour, the city has been existed. Williams writes:"In the long history of human settlements, this connection between the land from which directly or indirectly we all get our living and the achievements of human society has been deeply known. And one of these achievements has been the city: the capital, the large town, a distinctive form of civilization (Williams, 1973, p.1).

Generally, achieved and civilized things can be seen as positive and negative. However; Williams considers them to be making a profound feeling of sentimentality for their inverse, which communicates in a hopeful origination of rurality. This accords with Bell's distinguishing proof of untainted rurality, a lost brilliant age, set against innovation. He states that the three driving inspirations for this construct are 'romanticism, authenticity and nostalgia, all stepped onto the land and its occupants, plants creatures, individuals, to live in a simple way (Bell, 2006, p.150). Williams continues to make a contrast what he calls 'the stereotype' with the real history by featuring the authentic and local assortment inside both urban and rural contexts. He states also that city is the capital of state, center of religion, trade center, military barracks, administrative base, and concentration of industries.

\section{Objectives of the study}

The main objectives of this study are:

1. Examine the construction of rural/urban culturally and socially; by an understanding of rurality focusing on the binary oppositions.

2. Investigates the historical background of rural/urban together.

3. Apply an understanding of rural/urban to Emily Brontë's Wuthering Heights as a case study.

\section{Wuthering Heights}

Wuthering Heights starts with the appearance of Lockwood at the eponymous house in 1801, somewhere in the range of forty six years before the date the novel was first distributed and seventeen years before Emily Brontë's birthday. It may hence be viewed as a work of recorded fiction. The portrayed occasions happen completely in rural upland Yorkshire and concern the undertakings of two neighboring families: Wuthering Heights and Thrushcross Grange. The events are described by Lockwood, a metropolitan respectable man looking for brief departure from city living, in the style of a diary or journal. Some of the time, Lockwood portrays occasions he has legitimately experienced. The vast majority of the novel, in any case, is as his review translation of the stories of different characters, mostly Nelly Dean, the maid at Wuthering Heights and later Thrushcross Grange. And lots of events if not all are narrated in the form of his 
VS Publications

Alford Council of International English \& Literature Journal(ACIELJ)

Impact Factor:4.401(SJIF)An International Peer-Reviewed English Journal

www.acielj.com

Vol-3,Issue-2,2020

ISSN:2581-6500

retrospective transcription of the narratives of other characters particularly Nelly Dean.

However; there are a number of basic responses to Wuthering Heights. The story's popularity and impact, together with its firmly established status as a stalwart of the English literary story is to such an extent that it is difficult to incorporate everything that has been expounded on it. It starts with Victorian analysis and gives unique account to them, since these are especially important to the thought of social mentalities during the advancement of urban/rural construct. The further methodologies illustrated are twentieth century humanism, formalism,psychoanalysis, Marxism, feminism, and postcolonialism.

Victoria's response to Wuthering Heights on its distribution was commonly unfriendly. Different American commentators communicated aversion. E. P. Whipple (referred to in Allott, 1974, p.247) considers the novel to be as portrayed by 'coarseness' and 'creature ferocities', while a mysterious analyst in Graham's Magazine trusted it to be a 'compound of indecent evil and unnatural abhorrences' (referred to in Allott, 1974, pp. 242-3). The Literary World weeps over the novel's 'appalling coarseness' nevertheless communicates awfulness at its capacity to captivate the reader: "we become interested in characters which are most revolting to our feelings" (referred to in Allott, 1974, p.233).

The story's capacity is viewed as undermined by its ethical purposelessness. American analyst George Washington Peck is especially mindful of its regionalism and rurality, and the suggestions this has as far as social chain of command and refinement, distinguishing its"annered contempt for the decencies of language, and in a style which might resemble that of a Yorkshire farmer"'(cited in Allott, 1974, p.235). However ; the geographical meaning of the novel is strongly influenced by the views of Peck:" We have been taken and carried through a new region, a melancholy waste, with here and there patches of beauty"'(cited in Allott, 1974, p.235). Furthermore, the savageness and roughness of dialogues and soliloquies are convicted by him. Wuthering Heights "lifts the veil and shows boldly the dark side of our depraved nature' (cited in Allott, 1974, p.240). "Nothing like it has ever been written before; it is to be hoped...for the sake of good manners, nothing will be hereafter"(cited in Allott, 1974, p.241).

The romantic tradition as one of the most discussed themes in Wuthering Heights is understood by Walter Pater" woven on a background of delicately beautiful moorland scenery" (cited in Allott, 1974, p.445). Additionally Mary Ward comprehends Emily's novel as part of the romantic tradition, "a revolt against classical models and restraints', representing 'the grafting of a European tradition upon a mind already richly stored with English and local reality" (cited in Allott, 1974, pp.456-7).

Storm and Calm as oppositional forces are examined carefully by Lord David Cecil, in 1934; he concentrates on the physical aspects of Wuthering Heights; therefore, he sees these oppositions as metaphor to describe the well-structured 
VS Publications

Alford Council of International English \& Literature Journal(ACIELJ)

Impact Factor:4.401(SJIF)An International Peer-Reviewed English Journal

www.acielj.com

Vol-3,Issue-2,2020

ISSN:2581-6500

settings of the novel:" The setting is a microcosm of the universal scheme as Emily Brontë conceived it. On the one hand, we have Wuthering Heights, the land of storm; high on the barren moorland, naked to the shock of the elements, the natural home of the Earnshaw family, fiery, untamed children of the storm. On the other, sheltered in the leafy valley below, stands Thrushcross Grange, the appropriate home of the children of calm, the gentle, passive, timid Lintons (cited in Allott, 1992, p.121).

In 1953, Dorothy Van Ghent studies the window figure and two children figure as two significant symbols in Wuthering Heights; however she thinks that these figures the structuring principles of Emily's Story. The two children' are Catherine and Heathcliff in the first half of the novel and Cathy and Linton and later Hareton in the second. Moreover, via the structuring figure, the oppositional realities are identified by Van Ghent:" the raw, inhuman reality of anonymous natural energies, and the restrictive reality of civilized habits, manners, and codes' (Van Ghent, 1953, p.157). Truthfully, the urban/rural oppositions are well incorporated in her study of Lockwood:" A city visitor in the country, a man whose very disinterestedness and facility of feeling and attention indicate the manifold emotional economies by which city people particularly protect themselves from any disturbing note of the ironic discord between civilized life and the insentient wild flux of nature in which it is islanded (Van Ghent, 1953, p.157).

Inevitably some of psychoanalytic approaches have applied Freudian theory to Wuthering Heights to depict an understanding of Emily's personality. Romer Wilson, Emilie and Georges Romieu see a clear evidence of parental oppression in Wuthering Heights; alongside, they see their writings as a means for repressed sexual desires. (1931, cited in Stoneman 1995, p.85). Themes of cruelty, violence and infanticide are the explored by Wade Thomson, who in 1963 applies Freudianism to the characters within the Wuthering Heights; he shows who Cathrin struggled to survive when she was enforced by the abnormal gender development represented by masculinity. On the other hand, Moser in 1962 studies Wuthering Heights as a proto-Freudian dramatization of the id(Heathcliff):" the source of psychic energy; the seat of the instincts (particularly sex and death); the essence of dreams; the archaic foundation of personality - selfish, asocial, impulsive" ( Moser, 1962,p.4).

Some perspectives have given on Wuthering Heights by Kettle in 1951; however he sees this novel explicitly Marxian. He interprets it as a part of social history. Kettle believes that the precise historical context and geographical and social setting of Wuthering Heights should be understood in terms of the material facts of the novel: "Wuthering Heights is about England in 1847. The people it reveals live not in a never-never land but in Yorkshire' (p.139). Heathcliff turns the tables on the Earnshaws and Lintons 'by the classic methods of the ruling class, expropriation and property deals"(Kettle,1951p.149).

The differences between English and Irish cultural understandings of the rural in Wuthering Heights have been interpreted by Eagleton in 1975. For the 
VS Publications

Alford Council of International English \& Literature Journal(ACIELJ)

Impact Factor:4.401(SJIF)An International Peer-Reviewed English Journal

www.acielj.com

Vol-3,Issue-2 ,2020

ISSN:2581-6500

English, nature is pastoral and bountiful under the control of its technocratic landlords; however, Brontë's novel, like Irish culture, depicts it "as harsh, niggardly, mean-spirited, and so as peasant rather than aristocrat" (Eagleton,1975, p.17). Therefore postcolonial critique with a Marxist inflection are entwined by Eagleton.

\section{Rurality/ Urbanity in Nature}

The concept of nature, emerging out of the Enlightenment, goes through the rural, which is additionally developed from Enlightenment sensibilities. In the event that nature is fundamentally other, mysterious, and set apart from mankind, at that point so is the rural. Landscape and spatial condition are the main parts of the urban/rural binary construct. However; mankind has produced the urban landscape. It is characterized by streets, building and other; it has developed upon the previous rural because of human undertaking. The undertaking itself has consistently been, by definition,artificial; however this simulation arrives at its apogee with the mechanical creation of artificial things.

Generally, people live in city are civilized; and their needs are artificial and constructed via civilized practices and innovation. While, on the other hand, the rural landscape is made from the natural elements found in nature. Farming and agriculture prepare rural effort and way of life. Rural life implies working and acting as indicated by the directs of the climate, the atmosphere the seasons, the rising and setting of the sun, instead of the ticking of the clock or the sound of the processing plant whistle. Agriculture, in addition, includes working with natural procedures: life, development, propagation, substantial procedures and demise. Rural individuals are familiar with experiencing presence as a cycle, in which waste and demise feed the land to give, and clear a path for, additional life, and on it goes. Rurality in this way requires or involves awareness with the twisted materiality of the body, of those parts of the body where it violates its own limits, and where even the feeling of a suffering self is deleted as it gets associated with the otherness of the material world.

It should be noted that reading Wuthering Heights indicates the antagonistic and promoting towards the nineteenth-century urban values; however, the opening texts of the novel needs higher interpretation. Furthermore, urban and rural cultures provided show how they are aligned themselves with highly growing sense of separation; in fact, they are observed to display such kind of forces. Perhaps, Thrushcross Grange is associated with city; but the reader doesn't see its cruelty and it is hidden than those of Wuthering Heights. However, the reader can re-categories Grange as rural, it's brutality is realized. Therefore, it is existed in a rural place, so it is rural and urban. On the other hand, Wuthering Heights is associated with rural because of the necessary of its structural settings, additionally, its cruelty is also associated with rural.

Nature is thoughtfully connected with the rural as a part of parallel grouping. The rural is what isn't simply the city, however is left to act naturally. It is the past - a setting into which the accomplishments of civilisation are 
VS Publications

Alford Council of International English \& Literature Journal(ACIELJ)

Impact Factor:4.401(SJIF)An International Peer-Reviewed English Journal

www.acielj.com

Vol-3,Issue-2,2020

ISSN:2581-6500

conceived. Nature, both as a logical idea

just as social idea, is related with the material and the physical which lies outside of human will, either through or notwithstanding human plan. The characteristic materiality of 'nature' is exhibited in the proceeded with contestation of its development by rural scholars who have come back to 'the good judgment thought that rural regions are more bountifully regular than towns and urban areas' (Castree and Braun, 2006, p.163).

The rural, close for what it's worth to nature, exemplifies the idea of the unyieldingly physical which is simultaneously the other of the void - that which is envisioned to sit outside of the content. While the city is the 'city of light', the rural is the 'rural of darkness'. Nature is the body, though civilisation is the thinking. Hence, another group of closely resembling ideas is uncovered. The rural is the physical, a spot where the body may rise above its limits. It in this way denies or overlooks the otherworldly, the scholarly and human will. As a spot where birth and passing are continually conjured and can't be overlooked, through rural cycles and procedures, the rural is a spot which offers ascend to dread and disturbance. As a token of death as a physical truth, and interlaces these with the informal parts of real reality. In his analysis of rabelaisian carnival, Bakhtin gives rise to the concept of grotesque reality:" When infused with grotesque imagery, objects transcend their own "natural" boundaries and become fused or linked with other things. From this is derived their pregnant and two-sided nature, the quality of "unfinished becoming" which is anathema to officialdom" (Gardiner, 1992, p.47).

Simultaneously, Wuthering Heights, can be seen not just as a result of, or channel for predominant ideological ideas, yet of a site of hugeness in which social powers, rationalistic powers maybe, are challenged, deciphered and used to impact further emphasis and proliferations of rurality. Accordingly, rurality, as the result of challenged powers, is persistently rethought in new ideological shapes which either fit in with or wander from prevailing worth frameworks.

The most controversial aspect of the concept of nature is the notion of human nature. However; religious, scientific understanding and philosophical systems construct this notion to sit together for reasons history, rather than accord. Human instinct is a socially created dynamic ancient rarity; its shape and substance molded by social impact. Maybe the focal thought around which renditions of human instinct challenge is that of oneself.

Burkitt (2008) follows the development of the Western origination of the self from Greco-Roman culture, drawing on Mauss' distinguishing proof of the Roman improvement of the idea of 'persona' as a political idea setting independence as a political personality associated with the need of citizenship inside Roman culture, and connected to the Greek thought of the mind as a mental and profound premise. Singular center turned into the drive for 'a custom of shaping a "narrative of self" that is as yet recognizable today' (Burkitt, 2008, p.5).

However; Catherine's relationship with Heathcliff presents a disturbing origination 
VS Publications

Alford Council of International English \& Literature Journal(ACIELJ)

Impact Factor:4.401(SJIF)An International Peer-Reviewed English Journal

www.acielj.com

Vol-3,Issue-2,2020

ISSN:2581-6500

of selfhood in Wuthering Heights. Surely, she contrasts her affection for him with that for Edgar Linton:" My love for Linton is like the foliage in the woods. Time will change it, I'm well aware, as winter changes the trees-my love for Heathcliff resembles the eternal rocks beneath - a source of little visible delight, but necessary. Nelly, Iam Heathcliff-he's always, always in my mind - not as a pleasure, any more than I am always a pleasure to myself - but, as my own being (WH, p.73).

"This is a direct violation of the Western concept of subjective individuality, in which human, fleshy, material bodies are whole and complete, and home to only one resident self. With one body and one self, each body exists separately and individually. Heathcliff is part of Catherine's being, part of, or a component of herself. She means this as more than mere metaphor, even though she appears to use a simile to illustrate this unification with Heathcliff. However, her choice of elements of nature in constructing her simile, work to make her meaning literal. The eternal rocks serve as an indication of the underlying 'natural' reality of their intermingled selves, contrasting with the 'natural' reality of her ephemeral love for Linton"(Sean Broome, 2015 ,p.132).

\section{Rurality/Urbanity in History}

Before passing to the history of the rural/urban; however, we may ask this question: When did the rural start?' An investigation of this inquiry can feature a portion of the issues that emerge when attempting to fix the beginning of this construct to a second in time. This infers a quick answer may be that the rustic has consistently existed, since its inverse, the urban, is by definition an artificial phenomena. The rural is essentially the previous circumstance into which the urban expanded.(Broome,2015,p.44).

The cultural roots of rurality are inspected in three different ways. However, the first one, the inception of the thought of rurality is investigated, educated by its condition inside a parallel pair, which relies upon the development of the classification of urbanity. Thought is given to the issues emerging from crediting social plans to specific periods. Such credit can include making presumptions about the degree to which observations, convictions and qualities are shared past the writings which are utilized to give proof. Also, a basic view is taken with respect to viewpoints which venture the urban/rural into preindustrial societies. It is contended that the urban/rural differentiation is new with the time of industrialisation and urbanization, and is instilled with values installed in the Enlightenment and capitalism. Thirdly, accounts which try to clarify the development of British industrialisation are considered as components of the unpredictable and opposing interrelation of implications with which the urban/rural double has been built, and which at last add to the valorisation of urbanity.(Broome,2015,p.42).

Inevitably, if we want to understand Wuthering Heights as a rural reading, we require some consideration of history. Furthermore, Eagleton adds:"readers do not of course encounter texts in a void: all readers are historically and socially positioned, and how they 
VS Publications

Alford Council of International English \& Literature Journal(ACIELJ)

Impact Factor:4.401(SJIF)An International Peer-Reviewed English Journal

www.acielj.com

Vol-3,Issue-2,2020

ISSN:2581-6500

interpret literary works will be deeply shaped by this fact"(Eagleton,1975, p.83).

Considering the recorded development of rurality as a 'category of thought '(Mormont, 1990, p.40) is pertinent to increasing a comprehension of the idea of its development as a component of a parallel pair. The conditions of the starting points of rurality must be inspected. As talked about in Chapter 3, the urban and the provincial are commonly characterizing - each is characterized by what it isn't: its perfect inverse. It is in this way important to consider how these classifications came to fruition and to arrange them verifiably. This is applicable in setting up the conditions of a new order between the two posts - in actuality the statement of a prevailing talk. Since these pairs are developments, looking at the recorded rise of the urban/rural isn't the assessment of material reality, however of noteworthiness. In any case, stories which are set up around the statement of material realities will be analyzed, since they are noteworthy in themselves. These stories place on the Enlightenment venture,capitalism, industrialisation and urbanization, terms which are grouped according to the eighteenth and nineteenth hundreds of years.

A further purpose behind considering history is that the composition and production of Wuthering Heights during the 1840s makes it a chronicled record. Wuthering Heights firmly implies rurality and was composed and distributed inside the chronicled period identifying with the rise of rurality. The impact of this on the development of rurality inside the content can't be disregarded. Furthermore, the ascent of the type of the novel and a thought of its readership and its place in culture must be noted. Wuthering Heights is a monumental novel which itself has an influence in the development of rurality( Broome, 2015,43).

The thought that urban focuses can be arranged on the whole as urban, while the domain which lies outside can be classified as a country continuum, with every classification sharing basic societies and personalities, is an advanced innovation which turns out to be full fledged during the period of industrialisation and urbanization in the eighteenth and nineteenth hundreds of years. As indicated by Landry (2001), the word ' countryside' came to signify 'a fanciful summed up space' as opposed to a particular zone, at some point between the Game Act of 1671 and its nullification in 1831. 'It turned into a thought, and a method for giving a fanciful, yet material, structure to a bound together, homogeneous vision of the country' (Landry,2001, p.1).

It is from this period that the contemporary origination of the urban/rural parallel rises. Urban/rustic comes about as a couple of topographical classifications, yet overall arrangement of social classifications including scene, condition, conduct, ethical quality, governmental issues and character. The making of the urban-rural double is situated in financial and chronicled and material conditions; it rises up out of industrialisation and urbanization, the building up of entrepreneur methods of creation and the social chains of importance made inside them, and from the subsequent social characters and 
VS Publications

Alford Council of International English \& Literature Journal(ACIELJ)

Impact Factor:4.401(SJIF)An International Peer-Reviewed English Journal

www.acielj.com

Vol-3,Issue-2,2020

ISSN:2581-6500

understanding dependent on examples of utilization and conduct.(Broome,2015,49).

The conditions of the rise of the urban/rural binary are bound up with the arrangement of thoughts that became out of the Enlightenment, and with the cognizant consciousness of the possibility of the advanced. The suggestions for the origination of the person just as for the state of society, have a solid bearing on the molding of originations of the urban and the rural. In understanding the significance of Enlightenment esteems,Jervis expects that:" the period to concentrate on is surely that from around the mid-eighteenth century, when modern notions of selfhood had become widely established, along with the matrix of 'civil society', and on into the nineteenth century and beyond, with the explosive implications of the technological, industrial and political transformations of the world" (Jervis, 1999, pp.4-5).

Landry makes an express association between the formation of the countryside as a social geological substance, and the development of a modern urban bourgeoisie over the most recent two many years of the eighteenth century. The point of view on the countryside is conflicting. From one viewpoint, the 'average sort' tried to connect status to their riches by receiving or appropriating social signifiers related with the privileged and the landed nobility. Simultaneously, an elective belief system developed, which envisioned the field inside the particulars of urban experience. It was a 'move in reasonableness with respect to chasing and handle sports'. The average urban experience was not used to the real factors of birth and demise, and dismissed the form of the wide open which included such brutalities. Urbanization 'had expelled numerous individuals from their previous vicinity to creatures in financial creation and conventional farming.' Landry recognizes the developing strength of urban bourgeois culture expanded to the that nation thoroughly:" The English became a nation of pet- owners"(Landry, 2001, p.7).

\section{Conclusion}

Studying of Wuthering Heights which focuses on nature as a classification of rural places uncovers some fascinating associations. Wuthering Heights manages the rural and nature can be viewed as a noteworthy part of the development of rurality. Inside the development of nature, the reception of the Bakhtinian idea of the strangeness is beneficial. Wuthering Heights depicts a scope of unusual practices and occasions. The portrayals of nature, and particularly of creatures inside the content, offers chance to watch real offense. Such offense, as a carnivalesque toppling of prevailing methods of thought which facilitate an arrangement of Western qualities, is at chances with a faith in the profound, or of the presence of an endless soul. An assault on these convictions is worryingly (for Victorians) at chances with a faith in Christian otherworldliness and with a Romantic perspective on nature as wonderful. Simultaneously, it affirms the faith in a materialistic world view suggested by a developing rationalistic and logical authority.

The connection between these contradicting thoughts and their direction towards the urban/rural opposition is mind boggling. The pragmatist realist position sees nature as unappeasable material 
VS Publications

Alford Council of International English \& Literature Journal(ACIELJ)

Impact Factor:4.401(SJIF)An International Peer-Reviewed English Journal

www.acielj.com

Vol-3,Issue-2 ,2020

ISSN:2581-6500

actuality, outside of the domain of humankind or human worth. It is accessible for domain and control through human communication. Inside this view nature is profoundly other. This, suggests a forswearing of customary perspectives on human and common pith as being steady and brought together and places the ephemerality of mankind, which is just the liquid arrangement and reconfiguration of issue, interminably violating the limits of self. It appears to ring with the twisted body, while testing the customary, otherworldly view.

Consequently, the rural is firmly associated with patterns of life and demise. It typifies the material truth of life as transient and vaporous (instead of everlasting). Wuthering Heights, sensationalizes the two belief systems. In the instinctive nearness of its animalia and the blending spoiled tissue of Catherine and Heathcliff, nature is here as material certainty. In the great depressingness of the fields which associate with Catherine and Heathcliff's beings on a significantly otherworldly level, and in the recommendation of their unceasing spooky nearness it finds a Romantic restriction. Wuthering Heights others the country on the two checks.

My own examination gets motivation from Marxian, feminism and postcolonial ways to deal with Wuthering Heights. I take a gander at the nearness of progression inside the content, applying this to inquiries of rurality, as opposed to class, sex or ethnicity. In doing as such, I draw on a Derrida's comprehension of the how significance is situated in the content, and of the development of paired restriction. I oppose the compulsion to credit authorial expectation to Brontë herself and center upon her novel as an area inside which the importance of rurality is both made, reproduced and interminably conceded. However; some critics have not broadly investigated the significance of rurality, in contrast with inquiries of class, sexual orientation and ethnicity. It is recommend that a rural perusing of Wuthering Heights may be applied profitably to other social antiques.

An investigation of the generally situated importance of rurality is vital in applying a country perusing to artistic writings. On account of Wuthering Heights, published in 1847, a great account of study about originations of rurality of that period is conveniently drawn closer by considering the authentic setting as indivisible from the content itself. The situating of Victorian culture comparable to ideas of rurality is problematic in that it involves the review projection of contemporary qualities. In this manner a country perusing must perceive the temporary and unforeseen nature of such an application.

Subjects pertinent for authentic discussion gather around the arrangement of thoughts set against the rise of the urban/rural opposition. The twofold itself is uncovered to be a result of urbanization adapted through its cutting edge development as a component of the procedure of industrialisation, instead of, as different reporters recommend, as a marvel with its underlying foundations in olden times. Reference to the twofold setup of urban and rural uncovers a differentiation from the ideas of focus and edge which support pre-mechanical originations. 
VS Publications

Alford Council of International English \& Literature Journal(ACIELJ)

Impact Factor:4.401(SJIF)An International Peer-Reviewed English Journal

www.acielj.com

Vol-3,Issue-2,2020

ISSN:2581-6500

A refocusing of urban/rural talk

around the subjects of social change in the time of industrialisation permits these topics to exhibit their commitment to urban/rural development. Challenged records of the causes of industrialisation uncover their mutual social presumptions about British (and by expansion Western) prevalence: experimentally, socially, strategically and socially.

Stories of social change show inseparable connections between understandings of industrialisation, social change, the improving of social chains of command and the rise of the rustic as a 'class of suspected', setting contemporary originations of rurality inside this convention. Different methodologies see that the rural has been reproduced as a spot for utilization as much concerning creation, and this thought arranges this inside the procedure of industrialisation and urbanization. Truth be told, this 'utilization of the rural', corresponds with its very creation.

\section{References}

\section{Primary text}

[1]Brontë, E., Jack, I., \& Stoneman, P. (1998) Wuthering Heights. Oxford: Oxford University Press.

\section{Secondary texts}

[1]Allott, M. (ed.) (1992) Emily Brontë: Wuthering Heights. A Casebook. New edition. Basingstoke: Macmillan.

[2]Bell, D. (2006) 'Variations on the rural idyll', in Cloke, P. et al. (eds.) The Handbook of Rural Studies. London: Sage, pp.149-160.

[3]Broom, Sean.(2015)Wuthering Heights and the Othering of the Rural. Derby: University of Derby.
[4]Burkitt, I. (2008) Social Selves:

Theories of Self and Society. London: Sage.

[5]Castree, N. \& Braun, B. (2006) 'Constructing Rural Natures', in Cloke, P. et al. (eds.) The Handbook of Rural Studies. London: Sage, pp.161-170.de Man, P. (1979) Allegories of Reading: Figural Language in Rousseau, Nietzsche, Rilke, and Proust. New Haven: Yale University Press.

[6]Eagleton, T. (1975) 'Myths of Power in Wuthering Heights', reprinted in Stoneman, P., ed. (1993) Wuthering Heights. Basingstoke: Macmillan, pp. 118130.

[7]Frith, G. (1997) 'Decoding Wuthering Heights' in Winnifrith, T. J. (ed.) Critical Essays on Emily Brontë, New York: G.K. Hall, pp.243-262.

[8]Gardiner, M. (1992) The Dialogics of Critique: M. M. Bakhtin and the theory of Ideology. London: Routledge.

[9]Hawkes, T. (2003) Structuralism and Semiotics. London and New York: Routledge.

[10]Jervis, J. (1999) Transgressing the Modern: Explorations in the Western Experience of Otherness. Oxford: Blackwell.

[11]Kettle, A. (1951) An Introduction to the English Novel, Vol.1. London: Hutchinson.

[12]Landry, D. (2001) The Invention of the Countryside: Hunting, walking and Ecology in English Literature, 1671-1831. Basingstoke: Palgrave.

[13]Lyons, J. (1977) Semantics, Vol. 1. Cambridge: Cambridge University Press.

McKeon, R. (ed.) (1941) The Basic Works of Aristotle. New York: Random House. 
VS Publications

Alford Council of International English \& Literature Journal(ACIELJ)

Impact Factor:4.401(SJIF)An International Peer-Reviewed English Journal www.acielj.com

[14]Moser, T. (1962) 'What is the Matter with Emily Jane? Conflicting Impulses within Wuthering Heights', in NineteenthCentury Fiction, 17, pp. 1-19.

[15]Stoneman, P. (1995) 'Introduction', in Jack, I. (ed.) Wuthering Heights by Emily Brontë. Oxford: Oxford University press, pp. vii-xxxvi.

[16]Van Ghent, D. (1953) The English Novel: Form and Fiction. New York: Rinehart \& Company.

[17]Williams, R. (1973) The Country and the City. St Albans: Paladin. 